\title{
CRISPR typing of Campylobacter jejuni reveals a link between CRISPR array preservation and Guillain- Barré syndrome
}

\section{Yameen Hamid}

International Centre for Diarrhoeal Disease Research

Israt Jahan

International Centre for Diarrhoeal Disease Research

Shoma Hayat

International Centre for Diarrhoeal Disease Research

Mohammad Imtiazur Rahman

Arizona State University

Asaduzzaman Asad

International Centre for Diarrhoeal Disease Research

Avizit Das

Jashore University of Science and Technology

Zhahirul Islam ( $\sim$ zislam@icddrb.org )

International Centre for Diarrhoeal Disease Research

\section{Research Article}

Keywords: Guillain-Barré syndrome, Campylobacter jejuni, CRISPR typing, CRISPR array preservation

Posted Date: May 5th, 2021

DOI: https://doi.org/10.21203/rs.3.rs-453681/v1

License: () (i) This work is licensed under a Creative Commons Attribution 4.0 International License. Read Full License 


\section{Abstract}

Guillain-Barré syndrome (GBS) is a post-infection sequela of Campylobacter jejuni-induced enteritis. Clustered regularly interspaced short palindromic repeats and associated genes (CRISPR-Cas) confers adaptive immunity and plays role in virulence in many bacteria. We investigated $C$. jejuni CRISPR type (CT) to explore association of CRISPR-Cas with risk of developing GBS. We analysed CRISPR-Cas in C. jejuni isolated from 30 patients with GBS, 60 patients with enteritis and 52 healthy controls from Bangladesh. CRISPR types were determined by PCR followed by CRISPR array sequencing. Statistical and genomic analyses were performed using SPSS and multiple web-based software respectively. We found preserved CRISPR array was significantly more frequent in GBS-related strains than healthy control-related strains ( $P$ $=0.02, \mathrm{OR}=2.95)$. Increased CRISPR array length was significantly associated with GBS compared to healthy control- $(P=0.003, \mathrm{AUC}=0.7)$ and enteritis-related strains $(P=0.02, \mathrm{AUC}=0.65)$. We reported 38 new CT found among 70 CRISPR-preserving strains. CT of GBS-related strains were unique from enteritisand healthy control-related strains. Eighty spacers, including 20 novel spacers, were identified among the CRISPR-preserving strains. CRISPR typing had more discriminatory power than PCR-based subtyping in enteritis- and healthy control-related strains. Further genomic analyses are warranted to elucidate role of the $C$. jejuni CRISPR array in GBS pathogenesis.

\section{Introduction}

Campylobacter jejuni is a leading cause of bacterial gastroenteritis worldwide and the most frequent antecedent event associated with the post-infection sequela, Guillain-Barré syndrome (GBS) ${ }^{1-3}$. Molecular mimicry between bacterial lipopolysaccharide (LPS) and host nerve gangliosides is the apparent cause of pathogen-derived GBS in a susceptible host ${ }^{4,5}$. However, not all $C$. jejuni-infected individuals develop GBS after enteritis ${ }^{6}$. In addition to host susceptibility factors ${ }^{7-10}$, bacterial virulence factors also function as key regulatory elements that may trigger GBS ${ }^{11-13}$. Moreover, the cst-I/ sialyltransferase gene of $C$. jejuni, which encodes ganglioside-like structures expressed on the bacterial cell surface, has been linked to GBS 14. In addition to disease pathogenesis, cst-I/ has been shown to confer efficient bacteriophage resistance in $C$. jejuni along with a functionally complex adaptive immune system, the type II Clusters Regularly Interspaced Short Palindromic Repeat and associated genes (CRISPR-Cas) ${ }^{15}$.

The CRISPR-Cas system is a repeat region of numerous archaeal and bacterial DNA sequences that provides adaptive immunity against invading phages and plasmids by targeting their nucleic acids in a sequence-specific manner ${ }^{16-18}$. The latest CRISPR-Cas system classification includes two major classes, six types and 33 subtypes based on organizational variation in the Cas genes ${ }^{19}$. The $C$. jejuni genome harbours a class 2, type II-C CRISPR-Cas system comprised of a Cas9-Cas1-Cas2 operon followed by a trans-activating CRISPR-RNA (tracrRNA) region and CRISPR repeat-spacer array, which is transcribed in the opposite direction ${ }^{20}$. The CRISPR array in $C$. jejuni is composed of multiple 36-bp tandem consensus direct repeats (DRs) separated by 'spacer' sequences of similar length (30 bp) acquired from an invading foreian phaqe or plasmid ${ }^{21,22}$. 
In addition to conferring adaptive immunity against invading foreign DNA, the CRISPR-Cas system also plays a role in regulation of virulence genes, competition between mobile genetic elements (MGEs), DNA repair, gene regulation of group behaviour, and the acquisition of antibiotic resistance genes and pathogenicity islands ${ }^{23,24}$. The type II-C CRISPR-Cas system exerts regulatory roles in pathogenicity, cell surface immunity, stress response bacterial physiology and anti-microbial resistance in many bacteria, including C. jejuni ${ }^{25,26}$.

Due to the presence of polymorphisms in the spacer alleles within the CRISPR array, CRISPR-based genotyping (CRISPR typing) of bacteria enables high-resolution genotyping of pathogenic bacteria, including $C$. jejuni isolates. CRISPR typing also provides an effective framework for epidemiologic source tracking, studies of genome microevolution and host-virus population dynamics ${ }^{27,28}$. A previous comparative genotyping study revealed diversity among genotypes and clonal complexes of various strains of $C$. jejuni isolated from chickens, individuals with enteritis and patients with GBS in Bangladesh ${ }^{29}$. Serotyping and comparative genomic analyses demonstrated certain serotypes and genotypes were overrepresented in $C$. jejuni isolates obtained from Bangladeshi patients with GBS ${ }^{30,31}$. Thus, this study aimed to determine the CRISPR types (CTs) in C. jejuni-related strains and explore the association between preservation of the CRISPR-Cas sequence and the risk of developing GBS in Bangladesh.

\section{Results}

\section{Distribution of CRISPR-Cas components in C. jejuni}

CRISPR array was detected in $67 \%$ of the GBS-related, $48 \%$ of the enteritis-related and $40 \%$ of the healthy control-related $C$. jejuni strains (Table 1). There were no significant differences in the frequencies of the Cas genes (Cas1, Cas2 and Cas9) between the groups of $C$. jejuni strains related to GBS, enteritis and healthy controls. All GBS-associated strains and almost $90 \%$ of the enteritis and healthy control-related $C$. jejuni strains were positive for at least one Cas gene (Table 1). 
Table 1

Distribution of CRISPR-Cas components in $C$. jejuni strains isolated from patients with GBS, enteritis and healthy controls. ${ }^{a}$ Indicates significant difference of CRISPR array preservation among $C$. jejuni strains isolated from GBS and healthy controls. ${ }^{\mathrm{b}}$ Calculating OR was not applicable as all GBS related C. jejuni strains contained Cas genes (Cas1, Cas2, Cas9).

\begin{tabular}{|c|c|c|c|c|c|c|c|c|c|}
\hline \multirow[t]{2}{*}{$\begin{array}{l}\text { CRISPR-Cas } \\
\text { components }\end{array}$} & \multicolumn{3}{|c|}{ Source of $C$. jejuni isolates } & \multicolumn{2}{|c|}{$\begin{array}{l}\text { GBS vs. } \\
\text { enteritis }\end{array}$} & \multicolumn{2}{|c|}{$\begin{array}{l}\text { GBS vs. } \\
\text { healthy } \\
\text { controls }\end{array}$} & \multicolumn{2}{|c|}{$\begin{array}{l}\text { Enteritis vs. } \\
\text { healthy } \\
\text { controls }\end{array}$} \\
\hline & $\begin{array}{l}\text { GBS } \\
n=30 \\
(\%)\end{array}$ & $\begin{array}{l}\text { Enteritis } \\
\mathrm{n}=60 \\
(\%)\end{array}$ & $\begin{array}{l}\text { Healthy } \\
\text { controls } \\
\mathrm{n}=52 \\
(\%)\end{array}$ & $\begin{array}{l}\mathrm{P}- \\
\text { value }\end{array}$ & $\begin{array}{l}\text { OR } \\
\text { (95\% } \\
\text { Cl) }\end{array}$ & $\begin{array}{l}\text { P- } \\
\text { value }\end{array}$ & $\begin{array}{l}\text { OR } \\
(95 \% \\
\text { Cl) }\end{array}$ & $\begin{array}{l}\mathrm{P} \text { - } \\
\text { value }\end{array}$ & $\begin{array}{l}\text { OR } \\
\text { (95\% } \\
\text { Cl) }\end{array}$ \\
\hline $\begin{array}{l}\text { Preserved } \\
\text { CRISPR } \\
\text { array }\end{array}$ & $\begin{array}{l}20 \\
(67 \%)\end{array}$ & $\begin{array}{l}29 \\
(48 \%)\end{array}$ & $\begin{array}{l}21 \\
(41 \%)\end{array}$ & 0.07 & $\begin{array}{l}2.14 \\
(0.85- \\
5.32)\end{array}$ & $0.02^{\mathrm{a}}$ & $\begin{array}{l}2.95 \\
(1.15- \\
7.56)\end{array}$ & 0.26 & $\begin{array}{l}1.38 \\
(0.65- \\
2.92)\end{array}$ \\
\hline Cas1 & $\begin{array}{l}30 \\
(100 \%)\end{array}$ & $\begin{array}{l}53 \\
(88 \%)\end{array}$ & $\begin{array}{l}47 \\
(89 \%)\end{array}$ & $N A^{b}$ & $N A^{b}$ & $N A^{b}$ & $N A^{b}$ & 0.59 & $\begin{array}{l}0.97 \\
(0.3- \\
3.08)\end{array}$ \\
\hline Cas2 & $\begin{array}{l}30 \\
(100 \%)\end{array}$ & $\begin{array}{l}54 \\
(90 \%)\end{array}$ & $\begin{array}{l}46 \\
(87 \%)\end{array}$ & $N A^{b}$ & $N A^{b}$ & $N A^{b}$ & $N A^{b}$ & 0.4 & $\begin{array}{l}1.34 \\
(0.43- \\
4.36)\end{array}$ \\
\hline Cas9 & $\begin{array}{l}30 \\
(100 \%)\end{array}$ & $\begin{array}{l}54 \\
(90 \%)\end{array}$ & $\begin{array}{l}48 \\
(91 \%)\end{array}$ & $N A^{b}$ & $N A^{b}$ & $N A^{b}$ & $N A^{b}$ & 0.58 & $\begin{array}{l}0.94 \\
(0.27- \\
3.27)\end{array}$ \\
\hline
\end{tabular}

\section{CRISPR array preservation and GBS}

A preserved CRISPR array was significantly more frequent among the GBS-related strains than the healthy control-related strains (Odds ratio, OR: 2.95, 95\% confidence interval, Cl: $1.15-7.56, P$ value $=0.02$ ), but not the enteritis-related strains (Table 1). Longer CRISPR arrays were more common among GBS-related strains than both the healthy control-related strains (Nagelkerke $R^{2}=0.142, P=0.0026$, area under ROC curve $[\mathrm{AUC}]=0.70$; Fig. $1 \mathrm{a}$ ) and enteritis-related strains (Nagelkerke $R^{2}=0.084, P=0.018, \mathrm{AUC}=0.65$; Fig. 1b).

\section{CRISPR types in C. jejuni}

PCR-based rapid screening revealed a total of seven CRISPR subtypes across all 142 C. jejuni isolates (Table 2). Amplicon lengths of $0 \mathrm{bp}$ (negative in the F2 primer PCR assay) and $190 \mathrm{bp}$ were not considered as subtypes, as they either did not harbour any CRISPR array or did not contain any spacer in their CRISPR array. Two subtypes were not detected in the GBS-related strains (330 bp and 720 bp; Table 2) and two subtypes were not detected in the enteritis-related strains (530 bp and $590 \mathrm{bp}$; Table 2); the other three subtypes were ubiquitously detected in the GBS-, enteritis- and healthy control-related strains. 
Table 2

PCR-based detection of CRISPR subtypes in $C$. jejuni strains isolated from patients with GBS, enteritis and healthy controls. ${ }^{a}$ Indicates PCR amplicon length in PCR assay with F2 and R primers (Fig. 4). ${ }^{\mathrm{b}}$ These $C$. jejuni strains do not contain any CRISPR array.

\begin{tabular}{|c|c|c|c|c|c|}
\hline $\begin{array}{l}\text { PCR amplicon } \\
\text { length }(L \text { bp })^{\mathrm{a}}\end{array}$ & $\begin{array}{l}\text { CRISPR array length } \\
(L-155) \text { bp }\end{array}$ & $\begin{array}{l}\text { C. jejuni } \\
\text { isolated from }\end{array}$ & $\begin{array}{l}\text { Frequency } \\
n=142 \\
(\%)\end{array}$ & $\begin{array}{l}\text { Spacer } \\
\text { number }\end{array}$ & $\begin{array}{l}\text { Repeat } \\
\text { number }\end{array}$ \\
\hline \multirow[t]{3}{*}{190} & \multirow[t]{3}{*}{35} & GBS & $5(3 \%)$ & \multirow[t]{3}{*}{0} & \multirow[t]{3}{*}{1} \\
\hline & & Enteritis & $25(17 \%)$ & & \\
\hline & & $\begin{array}{l}\text { Healthy } \\
\text { controls }\end{array}$ & $17(12 \%)$ & & \\
\hline \multirow[t]{3}{*}{260} & \multirow[t]{3}{*}{105} & GBS & $3(2 \%)$ & \multirow[t]{3}{*}{1} & \multirow[t]{3}{*}{2} \\
\hline & & Enteritis & $15(10 \%)$ & & \\
\hline & & $\begin{array}{l}\text { Healthy } \\
\text { controls }\end{array}$ & $9(6 \%)$ & & \\
\hline \multirow[t]{3}{*}{330} & \multirow[t]{3}{*}{175} & GBS & $0(0 \%)$ & \multirow[t]{3}{*}{2} & \multirow[t]{3}{*}{3} \\
\hline & & Enteritis & $5(3 \%)$ & & \\
\hline & & $\begin{array}{l}\text { Healthy } \\
\text { controls }\end{array}$ & $3(2 \%)$ & & \\
\hline \multirow[t]{3}{*}{390} & \multirow[t]{3}{*}{235} & GBS & $5(3 \%)$ & \multirow[t]{3}{*}{3} & \multirow[t]{3}{*}{4} \\
\hline & & Enteritis & $3(2 \%)$ & & \\
\hline & & $\begin{array}{l}\text { Healthy } \\
\text { controls }\end{array}$ & $4(3 \%)$ & & \\
\hline \multirow[t]{3}{*}{460} & \multirow[t]{3}{*}{305} & GBS & $7(5 \%)$ & \multirow[t]{3}{*}{4} & \multirow[t]{3}{*}{5} \\
\hline & & Enteritis & $4(3 \%)$ & & \\
\hline & & $\begin{array}{l}\text { Healthy } \\
\text { controls }\end{array}$ & $2(1 \%)$ & & \\
\hline \multirow[t]{3}{*}{530} & \multirow[t]{3}{*}{375} & GBS & $1(1 \%)$ & \multirow[t]{3}{*}{5} & \multirow[t]{3}{*}{6} \\
\hline & & Enteritis & $1(1 \%)$ & & \\
\hline & & $\begin{array}{l}\text { Healthy } \\
\text { controls }\end{array}$ & $1(1 \%)$ & & \\
\hline \multirow[t]{3}{*}{590} & \multirow[t]{3}{*}{435} & GBS & $4(3 \%)$ & \multirow[t]{3}{*}{6} & \multirow[t]{3}{*}{7} \\
\hline & & Enteritis & $0(0 \%)$ & & \\
\hline & & $\begin{array}{l}\text { Healthy } \\
\text { controls }\end{array}$ & $1(1 \%)$ & & \\
\hline
\end{tabular}




\begin{tabular}{|c|c|c|c|c|c|}
\hline $\begin{array}{l}\text { PCR amplicon } \\
\text { length }(L \text { bp })^{a}\end{array}$ & $\begin{array}{l}\text { CRISPR array length } \\
(L-155) \text { bp }\end{array}$ & $\begin{array}{l}\text { C. jejuni } \\
\text { isolated from }\end{array}$ & $\begin{array}{l}\text { Frequency } \\
n=142 \\
(\%)\end{array}$ & $\begin{array}{l}\text { Spacer } \\
\text { number }\end{array}$ & $\begin{array}{l}\text { Repeat } \\
\text { number }\end{array}$ \\
\hline \multirow[t]{3}{*}{720} & \multirow[t]{3}{*}{565} & GBS & $0(0 \%)$ & \multirow[t]{3}{*}{8} & \multirow[t]{3}{*}{9} \\
\hline & & Enteritis & $1(1 \%)$ & & \\
\hline & & $\begin{array}{l}\text { Healthy } \\
\text { controls }\end{array}$ & $1(1 \%)$ & & \\
\hline \multirow[t]{3}{*}{ Negative $^{b}$} & \multirow[t]{3}{*}{ Not applicable } & GBS & $5(3 \%)$ & \multirow{3}{*}{$\begin{array}{l}\text { Not } \\
\text { applicable }\end{array}$} & \multirow{3}{*}{$\begin{array}{l}\text { Not } \\
\text { applicable }\end{array}$} \\
\hline & & Enteritis & $6(4 \%)$ & & \\
\hline & & $\begin{array}{l}\text { Healthy } \\
\text { controls }\end{array}$ & $14(10 \%)$ & & \\
\hline
\end{tabular}

Spacer polymorphism-based CRISPR typing identified seven CTs in the GBS-related strains, 22 CTs in the enteritis-related strains and 19 CTs in the healthy control-related strains (Table 3). Six CTs were found in both the enteritis- and healthy control-related strains. However, all seven CTs found in the GBS-related strains were absent in the enteritis- and healthy control-related strains (see Supplementary Table S1 online). Moreover, based on the presence of unique spacer arrangements that did not match with any $C$. jejuni CRISPR array sequence in the NCBI nucleotide database, 38 novel CTs were detected among the 42 $\mathrm{CTs}^{32}$. The most frequent CT among the GBS-related strains was CT 1. CT 9 was most frequent among enteritis-related strains, and CT 18 and CT 42 were most frequent among healthy control-related strains (see Supplementary Table S1 online). Spacer polymorphism-based CRISPR typing had a significantly higher discriminatory power than PCR-based typing in both the enteritis-related and healthy control-related C. jejuni strains (SID $=0.97$ and 0.99 , respectively; Table 3 ). However, due to the low (or lack of) variation in spacer arrangement within CRISPR arrays of the same length, PCR-based typing and sequence-based typing had similar discriminatory power among the GBS-related $C$. jejuni strains (SID $=0.79$ and 0.83 , respectively; Table 3). 
Table 3

Discriminatory power of CRISPR typing and subtyping methods for $C$. jejuni strains isolated from patients with GBS, enteritis and healthy controls.

\begin{tabular}{|c|c|c|c|c|c|}
\hline $\begin{array}{l}\text { C. jejuni } \\
\text { isolated } \\
\text { from }(n)\end{array}$ & $\begin{array}{l}\text { Frequency of } C \text {. } \\
\text { jejuni isolates with } \\
\text { preserved CRISPR } \\
\text { array (\%) }\end{array}$ & $\begin{array}{l}\text { CRISPR } \\
\text { genotyping/subtyping } \\
\text { method }\end{array}$ & $\begin{array}{l}\text { Number of } \\
\text { found } \\
\text { subtypes/CT }\end{array}$ & $\begin{array}{l}\text { Simpson's } \\
\text { index of } \\
\text { diversity } \\
(\text { SID })^{d}\end{array}$ & $\begin{array}{l}\text { Jackknife } \\
\mathrm{Cl}(95 \%)\end{array}$ \\
\hline \multirow{2}{*}{$\begin{array}{l}\text { Patients } \\
\text { with GBS } \\
\text { (30) }\end{array}$} & \multirow[t]{2}{*}{$20(67 \%)$} & Sequencing & 7 & 0.83 & $\begin{array}{l}0.74- \\
0.92\end{array}$ \\
\hline & & PCR & 5 & 0.79 & $\begin{array}{l}0.70- \\
0.88\end{array}$ \\
\hline \multirow{2}{*}{$\begin{array}{l}\text { Patients } \\
\text { with } \\
\text { enteritis } \\
(60)\end{array}$} & \multirow[t]{2}{*}{$29(48 \%)$} & Sequencing & 22 & 0.97 & $0.93-1.00$ \\
\hline & & PCR & 5 & 0.73 & $\begin{array}{l}0.59- \\
0.85\end{array}$ \\
\hline \multirow{2}{*}{$\begin{array}{l}\text { Healthy } \\
\text { controls } \\
(52)\end{array}$} & \multirow[t]{2}{*}{$21(40 \%)$} & Sequencing & 19 & 0.99 & $0.97-1.00$ \\
\hline & & PCR & 7 & 0.78 & $\begin{array}{l}0.63- \\
0.93\end{array}$ \\
\hline
\end{tabular}

\section{CRISPR array spacer diversity}

We identified a total of 80 unique spacer sequences across all 70 CRISPR array-containing $C$. jejuni strains (see Supplementary Table S2 online). Sixteen common spacers were detected in the enteritis- and healthy control-related strains. However, the GBS-related strains only contained three spacers (alleles 1, 5, 23) common to the enteritis-related strains and three spacers (alleles 1, 5, 21) common to the healthy controlrelated strains (see Supplementary Table S1 online). Moreover, we identified 20 previously unreported novel spacer sequences ${ }^{33,34}$. Six spacers (alleles $8,23,32,40,42$ and 49; see Supplementary Table S2 online) contained at least one nucleotide polymorphism site. The UPGMA dendrogram revealed that the enteritis- and healthy control-related strains were more closely related than the GBS-related strains, indicating a distinctive pattern of spacer acquisition and arrangement within the CRISPR arrays of the GBS-related strains (Fig. 2).

\section{Features of target proto-spacers}

We found target proto-spacers within 62 of the 80 spacer sequences (see Supplementary Table S2 online). The target proto-spacers detected in 19 spacers from GBS-related strains, 31 spacers from enteritis-related strains and 28 spacers from healthy control-related strains were found in Campylobacter phages or plasmids. The most abundant proto-spacers were found in Campylobacter phage DA10 (NCBI accession Loading [MathJax]/jax/output/CommonHTML/jax.js pacers from GBS-related strains, 27 spacers from enteritis- 
related strains and 26 spacers from healthy control-related strains (see Supplementary Table S1 and Supplementary Table S2 online). Nine spacers from GBS-related strains, 10 spacers from enteritis-related strains and eight spacers from healthy control-related strains shared at least $80 \%$ homology with target proto-spacers found in non-Campylobacter phage or plasmids (see Supplementary Table S2 online). The sequence logo (Fig. 3) created by aligning the $3{ }^{`}$ downstream proto-spacer sequences ${ }^{33}$ identified 5 - $\mathbb{N} A Y A C$ - 3 as a putative proto-spacer adjacent motif (PAM) for the $C$. jejuni Cas 9 endonuclease.

\section{Discussion}

This study indicates that preservation of the CRISPR array in $C$. jejuni is strongly associated with the risk of developing GBS. In addition, the probability of developing GBS following $C$. jejuni infection increases significantly with the CRISPR array length. Moreover, we found the Campylobacter bacteriophage DA10 is targeted by the CRISPR-Cas system of the majority of $C$. jejuni strains with a preserved CRISPR array. Moreover, this study identified 38 novel CTs and 20 novel spacer sequences in the CRISPR array, and demonstrates that GBS-related $C$. jejuni strains contain unique CT patterns compared to enteritis- and healthy control-related strains.

The type II CRISPR-Cas system has previously been reported to be involved in endogenous gene expression and gene regulation, respond to envelope stress and regulate other physiological processes in bacteria 25,35 . The ability of the Cas 9 endonuclease to regulate the virulence genes of bacteria containing the type II CRISPR-Cas system were described in experimental studies of $C$. jejuni ${ }^{15,36}$, Francisella novicida ${ }^{37}$ and Neisseria meningitides ${ }^{38}$. C. jejuni strains harbouring the Cas 9 gene were found to be more virulent than strains that do not harbour Cas9 or contain a degenerated Cas9 gene ${ }^{15}$. Recently, Dugar et al. reported that $C$. jejuni Cas 9 can regulate gene expression by targeting endogenous mRNA ${ }^{39}$. However, the relationship between CRISPR array preservation and bacterial virulence or pathogenesis had not previously been assessed. This study provides the first evidence that preservation of the CRISPR array in $C$. jejuni is associated with the development of GBS, which suggests a preserved CRISPR array may contribute to virulence or immunogenicity by controlling the expression of bacterial genes that increase the risk of developing GBS.

The CRISPR array length depends on the number of spacers acquired by the bacteria (Fig. 4). In this study, we observed longer $C$. jejuni CRISPR arrays were associated with a higher probability of developing GBS. This observation can potentially be explained by the findings of Martynov et al., who reported that bacteria maintain the optimum numbers of spacers to gain an evolutionary benefit ${ }^{40}$. Additionally, Levin's mathematical model predicted that a preserved CRISPR array provides a competitive advantage to bacteria by facilitating long-term co-evolutionary arms races between phage and bacteria ${ }^{41}$. This study supports the mathematical prediction that bacteria prefer to maintain an optimum CRISPR array length.

We also confirmed that CRISPR array-based typing had more discriminatory power and sensitivity than PCR-based subtyping due to the highly polymorphic CRISPR arrays of enteritis- and healthy control-related C. jejuni strains; thus, CRISPR array-based typing may represent a superior genotyping method ${ }^{42}$. CRISPR-

Loading [MathJax]/jax/output/CommonHTML/jax.js her bacteria were previously reported ${ }^{45-47}$. Cardenas et al.

Page 8/18 
and Yeh et al. found CRISPR typing of $C$. jejuni had sufficient discriminatory power (SID) to be considered a useful genotyping method ${ }^{28,44}$. Our study provides additional evidence to suggest that CRISPR typing could represent a useful molecular detection tool for epidemiological source identification during outbreaks of GBS or $C$. jejuni-induced enteritis.

A major part of the genome of the recently discovered Campylobacter phage DA10 was found to be attacked by the $C$. jejuni CRISPR array ${ }^{48,49}$. Similarly, most of our CRISPR array-containing $C$. jejuni strains acquired spacers from the Campylobacter phage DA10.

This study has several limitations. Even though we used PCR-based CRISPR typing, the discriminatory power of CRISPR typing was not compared with traditional genotyping or serotyping methods such as pulsed-field gel electrophoresis (PFGE), multilocus sequence typing (MLST) or flaA serotyping.

Additionally, the sample size was relatively small and the significance of the association between $C$. jejuni CRISPR array preservation and the development of GBS needs to be verified by an experimental study.

Overall, this study reveals that preservation of the CRISPR array in C. jejuni may provide an additional evolutionary benefit during the immunopathogenesis of GBS, which establishes a link between CRISPR array preservation and the risk of disease development. Further studies of larger, multicentric cohorts and genomic analysis of the entire $C$. jejuni CRISPR-Cas system using an experimental study design are required to confirm the role of the $C$. jejuni CRISPR array in bacterial virulence and the pathogenesis of GBS.

\section{Methods}

\section{Study population}

We isolated 30 C. jejuni strains from the stools specimen of patients with GBS and 52 C. jejuni strains from ethnically matched healthy controls as part of a prospective case-control study at the icddr,b. In addition, we included 60 historical $C$. jejuni strains from patients with enteritis in this study. All patients with GBS fulfilled the National Institute of Neurological Disorders and Stroke (NINDS) diagnostic criteria for GBS ${ }^{50}$. This study was reviewed and approved by the Ethics Committee of the icddr,b, Dhaka, Bangladesh, and all participants provided written informed consent prior sample collection. All methods were carried out in accordance with relevant guidelines and regulations.

\section{Bacterial strains and growth}

Faecal samples were collected at the time of enrolment of each participant. $C$. jejuni were cultured on blood agar plates containing $5 \%$ sheep blood at $37^{\circ} \mathrm{C}$ for $48 \mathrm{~h}$ under microaerobic conditions $\left(6 \% \mathrm{O}_{2}, 7 \%\right.$ $\mathrm{CO}_{2}, 80 \% \mathrm{~N}_{2}, 7 \% \mathrm{H}_{2}$ ) using an Anoxomat system (Anoxomat ${ }^{\mathrm{TM}}$ Mart II, Drachten, The Netherlands). C. jejuni colonies were identified by oxidase, catalase and hippurate hydrolysis tests and confirmed by $C$. jejuni species-specific polymerase chain reaction (PCR) using the forward primer 5 
All confirmed strains were stored at $-80^{\circ} \mathrm{C}$ in brain heart infusion broth containing $15 \%$ glycerol until analysis $^{30}$.

\section{Extraction of bacterial genomic DNA}

Bacterial DNA was extracted from colonies collected from the blood agar plates using Qiagen Genomic DNA purification kits, according to the manufacturer's instructions (Qiagen, Venlo, the Netherlands). DNA samples were stored at $-20^{\circ} \mathrm{C}$ prior CRISPR typing.

\section{Determination of C. jejuni CRISPR-Cas components}

The components of the $C$. jejuni CRISPR-Cas system were detected by PCR. The first forward primer for the CRISPR array, F1 (see Supplementary Table S3 online), was designed to target the left flanking region (leader sequence) of the CRISPR array to detect confirmed or true CRISPR array loci ${ }^{28}$. The second forward primer for the CRISPR array, F2 (see Supplementary Table S3 online), was designed to overlap the first 13 nucleotides (Fig. 4) of the most common consensus direct repeat (DR) of $C$. jejuni in the CRISPRdb 22. The reverse primer for the CRISPR array was obtained from previously published studies ${ }^{42,43}$. The NCBI Basic Local Alignment Search Tool (BLAST), MUSCLE and OligoAnalyzer 3.1 were used to design the primers to detect the Cas genes ${ }^{36}$.

The amplification reactions were performed in $25 \mu \mathrm{L}$ PCR master mixes containing $\sim 10 \mathrm{ng}$ of $C$. jejuni chromosomal DNA, $0.2 \mu \mathrm{L}$ of each primer, $4 \mu \mathrm{L}$ of $5 \times$ PCR buffer, $1.6 \mu \mathrm{L}$ of $25 \mathrm{mM} \mathrm{MgCl}_{2}$ and $0.2 \mu \mathrm{L}$ Taq DNA polymerase enzyme on MJ Research PTC-200 ThermalCycler (Marshall Scientific, Hampton, NH, USA). The reaction conditions were initial denaturation at $95^{\circ} \mathrm{C}$ for $10 \mathrm{~min}$, followed by 35 cycles of $45 \mathrm{sec}$ denaturation at $94^{\circ} \mathrm{C}, 30 \mathrm{sec}$ annealing at different temperature for Cas 1, Cas2, Cas 9 and the CRISPR array showed in Supplementary Table S3 online and $40 \mathrm{sec}$ extension at $72^{\circ} \mathrm{C}$, and a final extension step at $72^{\circ} \mathrm{C}$ for $10 \mathrm{~min}$. PCR products were visualized by electrophoresis on $1.5 \%$ agarose gels using a Molecular Imager ${ }^{\circledR}$ Gel Doc ${ }^{\mathrm{TM}}$ XR + system (Bio-Rad Laboratories Inc., Hercules, CA, USA).

\section{CRISPR-based genotyping}

Initial subtyping of the $C$. jejuni isolates was based on the CRISPR array length determined by PCR screening ${ }^{52,53}$. The CRISPR array length was calculated by subtracting 155 from the size of the PCR product amplified using the F2 primer (Fig. 4). The number of spacers and DRs were determined from the size of the PCR products. The repeat number is always one greater than the spacer number, as each spacer is flanked by two DRs ${ }^{54}$. $C$. jejuni strains containing at least one spacer sequence in their CRISPR array were classified as having a preserved CRISPR array; otherwise, the strain was termed degenerate ${ }^{41}$.

The PCR products amplified from 20 GBS-, 29 enteritis- and 21 healthy control-related CRISPR array preserving $C$. jejuni isolates were purified using the ExoSAP-IT ${ }^{\circledR}$ PCR Product Cleanup Reagent (Affymetrix, Cleaveland, $\mathrm{OH}, \mathrm{USA}$ ) at $37^{\circ} \mathrm{C}$ for $15 \mathrm{~min}$, followed by $15 \mathrm{~min}$ inactivation at $80^{\circ} \mathrm{C}$. Cycle sequencing was carried out using the BigDye Terminator Kit (Perkin-Elmer Applied Biosystems, Foster City, CA, USA) and the final purified products were loaded onto an ABI 3500xL Automated Genetic Analyzer (Perkin-Elmer Loading [MathJax]/jax/output/CommonHTML/jax.js 
Applied Biosystems) to determine the spacer polymorphism-based CRISPR type (CT). Each unique spacer sequence was given an allele number based on its chronology of discovery (see Supplementary Table S2 online). Each unique spacer arrangement was annotated as a unique CRISPR type (CT). The sequences of the $C$. jejuni CRISPR arrays were deposited in GenBank under accession numbers MW561358 to MW561427.

\section{CRISPR array sequence analysis}

CRISPR array sequences were detected using the web-based software CRISPRFinder (https://crispr.i2bc.paris-saclay.fr/Server/) ${ }^{55}$ and queried using the web tool CRISPRTarget (http://crispr.otago.ac.nz/CRISPRTarget/crispr_analysis.html) to detect target proto-spacers in the spacer sequences using the GenBank-Phage, Refseq-Plasmid and Refseq-Viral databases ${ }^{56}$. The CRISPR array sequences were also screened using the Nucleotide BLAST web tool

(https://blast.ncbi.nlm.nih.gov/Blast.cgi) to determine novel CTs ${ }^{57}$. Phylogenetic analysis was performed using the UPGMA (unweighted pair group method with arithmetic mean) function of MEGAX software ${ }^{58}$. Sequence logo was created using the web tool WebLogo (https://weblogo.berkeley.edu/logo.cgi) ${ }^{59}$.

\section{Statistical analysis}

The discriminatory power of the various methods of CRISPR typing were compared by calculating Simpson's index of diversity (SID) with an online tool (http://www.comparingpartitions.info/?link=Tool) ${ }^{60}$. Association studies were conducted using the Chi-squared test and binary logistic regression. $P$-values < 0.05 were considered significant for associations and the fitness of regression model. Statistical analyses were performed using MedCalc software (version 19.6.4, MedCalc Software Ltd, Ostend, Belgium) and SPSS (version 20, SPSS Inc., Chicago, IL, USA) software.

\section{Declarations}

\section{Acknowledgment}

This research activity was funded by the Fogarty International Center, National Institute of Neurological Disorders and Stroke (NINDS) of the National Institutes of Health (NIH), USA, under Award Number K43TW011447 and icddr,b. icddr,b acknowledges with gratitude the commitment of the Government of Bangladesh to its research efforts and gratefully acknowledges the unrestricted support provided by the Governments of the People's Republic of Bangladesh, Canada, Sweden, and the UK. We thankfully acknowledge the neurologists who referred their patients to this study.

\section{Author contributions statement}

Z.I., M.I.R. and Y.H. conceptualized and designed the study; Y.H. and A.D. contributed to data acquisition. Y.H., A.D., I.J. and S.H. analysed and interpreted the data; A.A. submitted the sequencing data to GenBank; Y.H. drew schematic illustration of the CRISPR array; Y.H. wrote the first draft of the manuscript along with 
I.J. and S.H., which was critically reviewed by all other co-authors. The entire study was performed under Z.I. supervision. All authors gave their consent to publish the study.

\section{Additional information}

\section{Competing interest}

The authors declare no competing interest.

\section{Availability of data}

The datasets used and analysed during the current study are available from the corresponding author on reasonable request. The sequencing data are available from the National Center for Biotechnology Information (NCBI) GenBank under the accession number MW561358 to MW561427.

\section{References}

1. Allos, B. M. Campylobacter jejuni Infections: update on emerging issues and trends. Clin. Infect. Dis. 32, 1201-1206 (2001).

2. Kaakoush, N. O., Castaño-Rodríguez, N., Mitchell, H. M. \& Man, S. M. Global epidemiology of campylobacter infection.Clin. Microbiol. Rev.28, (2015).

3. Rees, J. H., Soudain, S. E., Gregson, N. A. \& Hughes, R. A. Campylobacter jejuni infection and GuillainBarre syndrome. NEngl J Med. 333, 1374-1379 (1995).

4. Godschalk, P. C. R. et al. Structural characterization of Campylobacter jejuni lipooligosaccharide outer cores associated with Guillain-Barré and Miller Fisher syndromes. Infect. Immun. 75, 1245-1254 (2007).

5. Karlyshev, A. V., Linton, D., Gregson, N. A., Lastovica, A. J. \& Wren, B. W. Genetic and biochemical evidence of a Campylobacter jejuni capsular polysaccharide that accounts for Penner serotype specificity. Mol. Microbiol. 35, 529-541 (2000).

6. Magira, E. E. et al. Differential Distribution of HLA-DQ $\beta / D R \beta$ Epitopes in the Two Forms of GuillainBarré Syndrome, Acute Motor Axonal Neuropathy and Acute Inflammatory Demyelinating Polyneuropathy (AIDP): Identification of DQ $\beta$ Epitopes Associated with Susceptibility to and P. J. Immunol. 170, 3074 LP - 3080(2003).

7. Jahan, I. et al. Toll-like receptor-4 299Gly allele is associated with Guillain-Barré syndrome in Bangladesh. Ann. Clin. Transl. Neurol. 6, 708-715 (2019).

8. Hayat, S. et al. Human leukocyte antigen-DQB1 polymorphisms and haplotype patterns in GuillainBarré syndrome. Ann. Clin. Transl. Neurol. 6, 1849-1857 (2019).

9. Hayat, S. et al. Fc-gamma IIla-V158F receptor polymorphism contributes to the severity of GuillainBarré syndrome. Ann. Clin. Transl. Neurol. 7, 1040-1049 (2020).

10. Hayat, S., Ahmad, O., Mahmud, I., Howlader, M. Z. H. \& Islam, Z. Association of matrix Loading [MathJax]/jax/output/CommonHTML/jax.js I severity of Guillain-Barré syndrome.J. Neurol. Sci.116908 
(2020).

11. Yuki, N. \& Kuwabara, S. Axonal Guillain-Barre syndrome: carbohydrate mimicry and pathophysiology. J. Peripher. Nerv. Syst. 12, 238-249 (2007).

12. Hughes, R., a, C. \& Cornblath, D. R. Guillain-Barré syndrome. Lancet. 366, 1653-1666 (2005).

13. Wim Ang, C., Jacobs, B. C. \& Laman, J. D. The Guillain-Barré syndrome: A true case of molecular mimicry. Trends Immunol. https://doi.org/10.1016/j.it.2003.12.004 (2004).

14. Yuki, N. Campylobacter sialyltransferase gene polymorphism directs clinical features of Guillain-Barré syndrome. Journal of neurochemistry. https://doi.org/10.1111/j.1471-4159.2007.04707.x (2007).

15. Louwen, R. et al. A novel link between Campylobacter jejuni bacteriophage defence, virulence and Guillain-Barré syndrome. Eur. J. Clin. Microbiol. Infect. Dis. 32, 207-226 (2013).

16. Barrangou, R. et al. CRISPR provides acquired resistance against viruses in prokaryotes. Science (80-.). 315, 1709-1712 (2007).

17. Jansen, R., Embden, J. D., Gaastra, W. \& Schouls, L. M. Identification of genes that are associated with DNA repeats in prokaryotes. Mol. Microbiol. 43, 1565-1575 (2002).

18. Mojica, F. J. M., Díez-Villaseñor, C., García-Martínez, J. \& Soria, E. Intervening sequences of regularly spaced prokaryotic repeats derive from foreign genetic elements. J. Mol. Evol. 60, 174-182 (2005).

19. Makarova, K. S. et al. Evolutionary classification of CRISPR-Cas systems: a burst of class 2 and derived variants. Nature Reviews Microbiology. https://doi.org/10.1038/s41579-019-0299-x (2020).

20. Chylinski, K., Le Rhun, A. \& Charpentier, E. The tracrRNA and Cas9 families of type II CRISPR-Cas immunity systems. RNA Biol. 10, 726-737 (2013).

21. Parkhill, J. et al. The genome sequence of the food-borne pathogen Campylobacter jejuni reveals hypervariable sequences. Nature. 403, 665-668 (2000).

22. Grissa, I., Vergnaud, G. \& Pourcel, C. The CRISPRdb database and tools to display CRISPRs and to generate dictionaries of spacers and repeats. BMC Bioinformatics. https://doi.org/10.1186/14712105-8-172 (2007).

23. Westra, E. R., Buckling, A. \& Fineran, P. C. CRISPR-Cas systems: Beyond adaptive immunity. Nat. Rev. Microbiol. 12, 317-326 (2014).

24. Gholizadeh, P., Aghazadeh, M., Asgharzadeh, M. \& Kafil, H. S. Suppressing the CRISPR/Cas adaptive immune system in bacterial infections. Eur. J. Clin. Microbiol. Infect. Dis. 36, 2043-2051 (2017).

25. Sampson, T. R. \& Weiss, D. S. CRISPR-Cas systems: new players in gene regulation and bacterial physiology.Front. Cell. Infect. Microbiol.4, (2014).

26. Shabbir, M. A. B. et al. The CRISPR-cas system promotes antimicrobial resistance in Campylobacter jejuni. Future Microbiol. https://doi.org/10.2217/fmb-2018-0234 (2018).

27. Barrangou, R. \& Dudley, E. G. CRISPR-Based Typing and Next-Generation Tracking Technologies. Annu. Rev. Food Sci. Technol. https://doi.org/10.1146/annurev-food-022814-015729 (2016).

28. de Cárdenas, I. et al. Efficacy of a typing scheme for Campylobacter based on the combination of true and awestionahle CRISPR I/ Microhiol Methods. https://doi.org/10.1016/j.mimet.2015.10.020

Loading [MathJax]/jax/output/CommonHTML/jax.js

Page $13 / 18$ 
(2015).

29. Islam, Z. et al. Comparative genotyping of Campylobacter jejuni strains from patients with GuillainBarré syndrome. PLoS One. 4, https://doi.org/10.1371/journal.pone.0007257 (2009).

30. Islam, Z. et al.Comparative population structure analysis of Campylobacter jejuni

31. from human and poultry origin in Bangladesh.Eur. J. Clin. Microbiol. Infect. Dis.

32. doi:10.1007/s10096-014-2184-x

33. Islam, Z. et al. Campylobacter jejuni HS: 23 and Guillain-Barré syndrome, Bangladesh. Emerg. Infect. Dis. 15, 1315 https://doi.org/10.3201/eid1508.090120 (2009).

34. Sayers, E. W. et al. Database resources of the National Center for Biotechnology Information. Nucleic Acids Res. https://doi.org/10.1093/nar/gkz899 (2020).

35. Pearson, B. M., Louwen, R., Van Baarlen, P. \& Van Vliet, A. H. M. Differential distribution of type II CRISPR-Cas systems in agricultural and nonagricultural campylobacter coli and campylobacter jejuni isolates correlates with lack of shared environments. Genome Biol. Evol. 7, 2663-2679 (2015).

36. Kovanen, S. M., Kivistö, R. I., Rossi, M. \& Hänninen, M. L. A combination of MLST and CRISPR typing reveals dominant Campylobacter jejuni types in organically farmed laying hens. J. Appl. Microbiol. https://doi.org/10.1111/jam.12503 (2014).

37. Sampson, T. R. et al. A CRISPR/Cas system mediates bacterial innate immune evasion and virulence (Nature(2013) 497 (254-257) DOI: 10.1038/nature12048). Nature (2013). doi:10.1038/nature12498

38. Shabbir, M. A. B. et al. The Involvement of the Cas 9 Gene in Virulence of Campylobacter jejuni. Front. Cell. Infect. Microbiol. 8, 285 (2018).

39. Jones, C. L., Sampson, T. R., Nakaya, H. I., Pulendran, B. \& Weiss, D. S. Repression of bacterial lipoprotein production by francisella novicida facilitates evasion of innate immune recognition. Cell. Microbiol. 14, 1531-1543 (2012).

40. Sampson, T. R., Saroj, S. D., Llewellyn, A. C., Tzeng, Y. L. \& Weiss, D. S. A CRISPR/Cas system mediates bacterial innate immune evasion and virulence. Nature. 497, 254-257 (2013).

41. Dugar, G. et al. CRISPR RNA-Dependent Binding and Cleavage of Endogenous RNAs by the Campylobacter jejuni Cas9.Mol. Cel/69, (2018).

42. Martynov, A., Severinov, K. \& Ispolatov, I. Optimal number of spacers in CRISPR arrays.PLoS Comput. Biol.13, (2017).

43. Levin, B. R. Nasty viruses, costly plasmids, population dynamics, and the conditions for establishing and maintaining CRISPR-mediated adaptive immunity in bacteria. PLoS Genet. 6, 1-12 (2010).

44. Schouls, L. M. et al. Comparative genotyping of Campylobacter jejuni by amplified fragment length polymorphism, multilocus sequence typing, and short repeat sequencing: Strain diversity, host range, and recombination. J. Clin. Microbiol. 41, 15-26 (2003).

45. Price, E. P., Smith, H., Huygens, F. \& Giffard, P. M. High-resolution DNA melt curve analysis of the clustered, regularly interspaced short-palindromic-repeat locus of Campylobacter jejuni. Appl. Environ. Microbiol. https://doi.org/10.1128/AEM.02702-06 (2007).

Loading [MathJax]/jax/output/CommonHTML/jax.js

Page 14/18 
46. Yeh, H. Y. \& Awad, A. Genotyping of Campylobacter jejuni Isolates from Poultry by Clustered Regularly Interspaced Short Palindromic Repeats (CRISPR). Curr. Microbiol. https://doi.org/10.1007/s00284020-01965-w (2020).

47. Shariat, N. et al. Subtyping of Salmonella enterica serovar newport outbreak isolates by CRISPRMVLST and determination of the relationship between CRISPR-MVLST and PFGE results. J. Clin. Microbiol. 51, 2328-2336 (2013).

48. Pourcel, C., Salvignol, G. \& Vergnaud, G. CRISPR elements in Yersinia pestis acquire new repeats by preferential uptake of bacteriophage DNA, and provide additional tools for evolutionary studies. Microbiology. 151, 653-663 (2005).

49. Horvath, P. et al. Diversity, activity, and evolution of CRISPR loci in Streptococcus thermophilus. J. Bacteriol. 190, 1401-1412 (2008).

50. Hooton, S. et al. Campylobacter bacteriophage DA10: An excised temperate bacteriophage targeted by CRISPR-cas. BMC Genomics. https://doi.org/10.1186/s12864-020-06808-3 (2020).

51. G, A. et al. Isolation and morphological characterization of new bacteriophages active against Campylobacter jejuni.Am. J. Clin. Microbiol. Antimicrob.(2018).

52. Asbury, A. K. \& Cornblath, D. R. Assessment of current diagnostic criteria for Guillain-Barré syndrome. Ann Neurol. 27, S21-4 (1990).

53. Linton, D., Lawson, A. J., Owen, R. J. \& Stanley, J. PCR detection, identification to species level, and fingerprinting of campylobacter jejuni and campylobacter coli direct from diarrheic samples. J. Clin. Microbiol. https://doi.org/10.1128/jcm.35.10.2568-2572.1997 (1997).

54. Fabre, L. et al. Crispr typing and subtyping for improved Laboratory surveillance of Salmonella infections. PLoS One. https://doi.org/10.1371/journal.pone.0036995 (2012).

55. Shariat, N. \& Dudley, E. G. CRISPRs: Molecular Signatures Used for Pathogen Subtyping. Applied and Environmental Microbiology. 80, 430-439 (2014).

56. Marraffini, L. A. \& Sontheimer, E. J. CRISPR interference: RNA-directed adaptive immunity in bacteria and archaea. Nature Reviews Genetics. https://doi.org/10.1038/nrg2749 (2010).

57. Grissa, I., Vergnaud, G. \& Pourcel, C. CRISPRFinder: a web tool to identify clustered regularly interspace short palindromic repeats. Nucleic Acids Res. 35, 52-57 (2007).

58. Biswas, A., Gagnon, J. N., Brouns, S. J. J., Fineran, P. C. \& Brown, C. M. CRISPRTarget: Bioinformatic prediction and analysis of crRNA targets. RNA Biol. https://doi.org/10.4161/rna.24046 (2013).

59. McGinnis, S., Madden, T. L. \& BLAST At the core of a powerful and diverse set of sequence analysis tools. Nucleic Acids Res. https://doi.org/10.1093/nar/gkh435 (2004).

60. Kumar, S., Stecher, G., Li, M., Knyaz, C. \& Tamura, K. MEGA X: Molecular evolutionary genetics analysis across computing platforms. Mol. Biol. Evol. https://doi.org/10.1093/molbev/msy096 (2018).

61. Crooks, G. E., Hon, G., Chandonia, J. M. \& Brenner, S. E. WebLogo: A sequence logo generator. Genome Res. https://doi.org/10.1101/gr.849004 (2004).

62. Hunter, P. R. \& Gaston, M. A. Numerical index of the discriminatory ability of typing systems: An Loading [MathJax]/jax/output/CommonHTML/jax.js sity. J. Clin. Microbiol. 26, 2465-2466 (1988). 
Figures
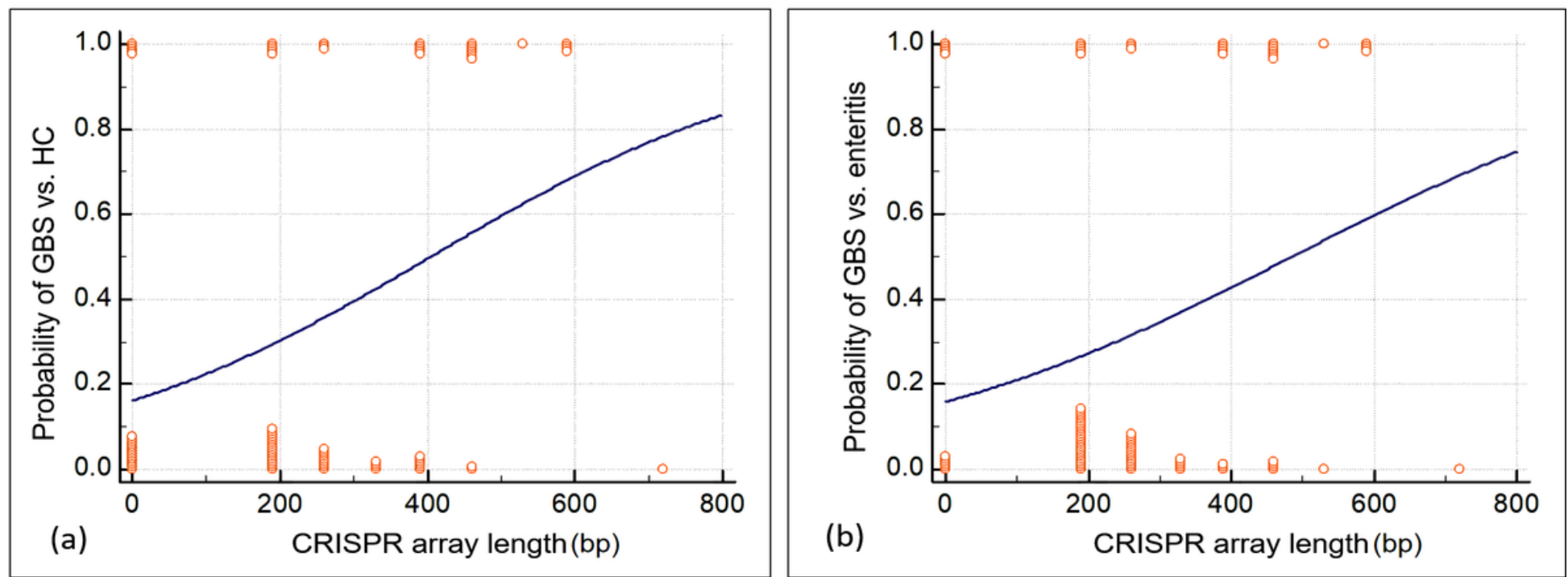

Figure 1

(a) Binary logistic regression curve (prepared using MedCalc software) predicting the probability of developing GBS following $C$. jejuni infection based on the $C$. jejuni CRISPR array length compared to healthy controls. (b) Binary logistic regression curve predicting the probability of developing GBS following C. jejuni infection based on the $C$. jejuni CRISPR array length compared to the probability of developing enteritis 


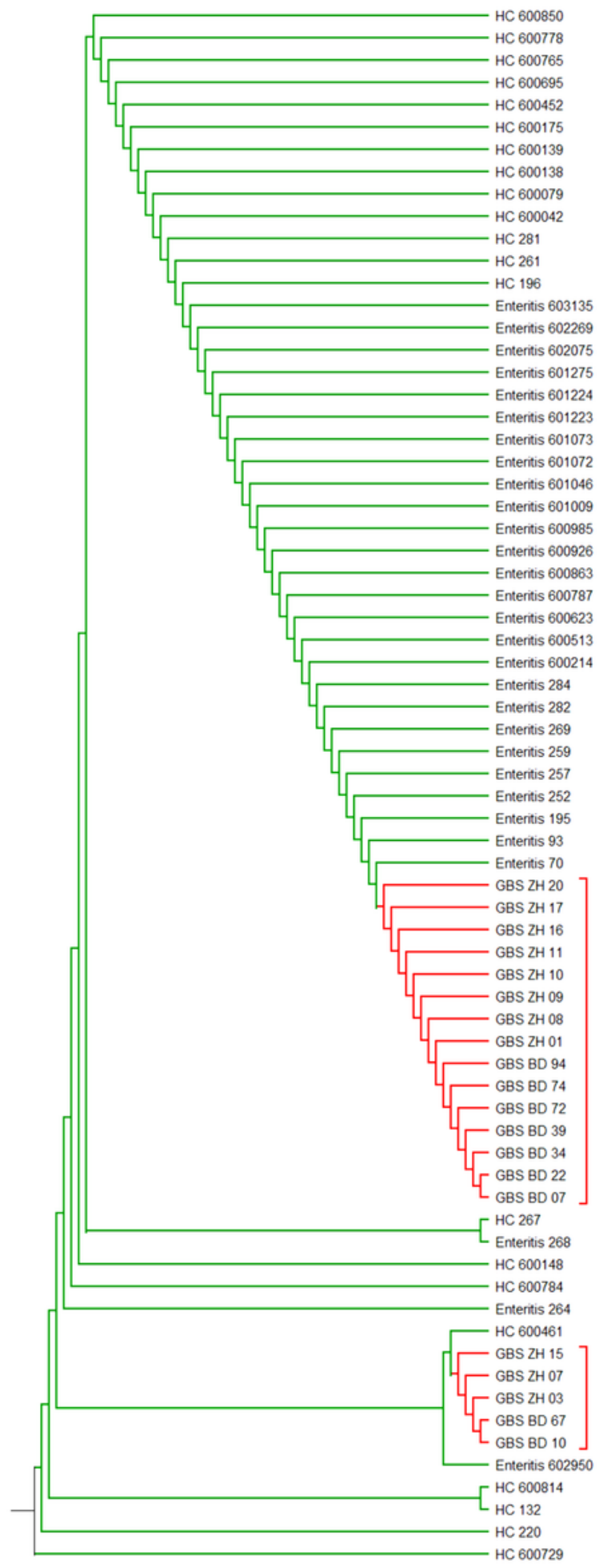

Figure 2

UPGMA dendrogram (prepared using MEGA X software) of C. jejuni CRISPR arrays from 20 strains isolated from patients with GBS, 29 strains isolated from patients with enteritis and 21 strains isolated from healthy controls. Clusters of GBS-related strains are indicated by red branches; clusters of enteritis and healthy control-related strains are indicated by green branches 


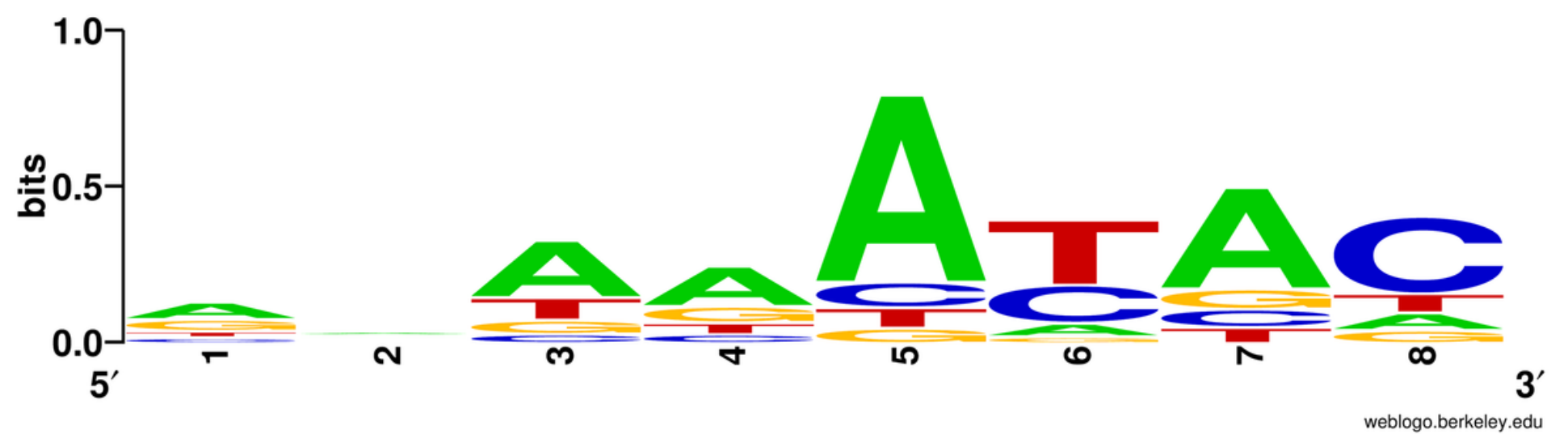

Figure 3

Sequence logo of the 3downstreampro $\rightarrow-$ spacersequences, $\in$ dicat $\in$ g3-NNNNAYAC-5 is the putative proto-spacer adjacent motif (PAM) of the Cas9 endonuclease in all 70 CRISPR array-containing C. jejuni strains isolated from patients with GBS, enteritis and healthy control

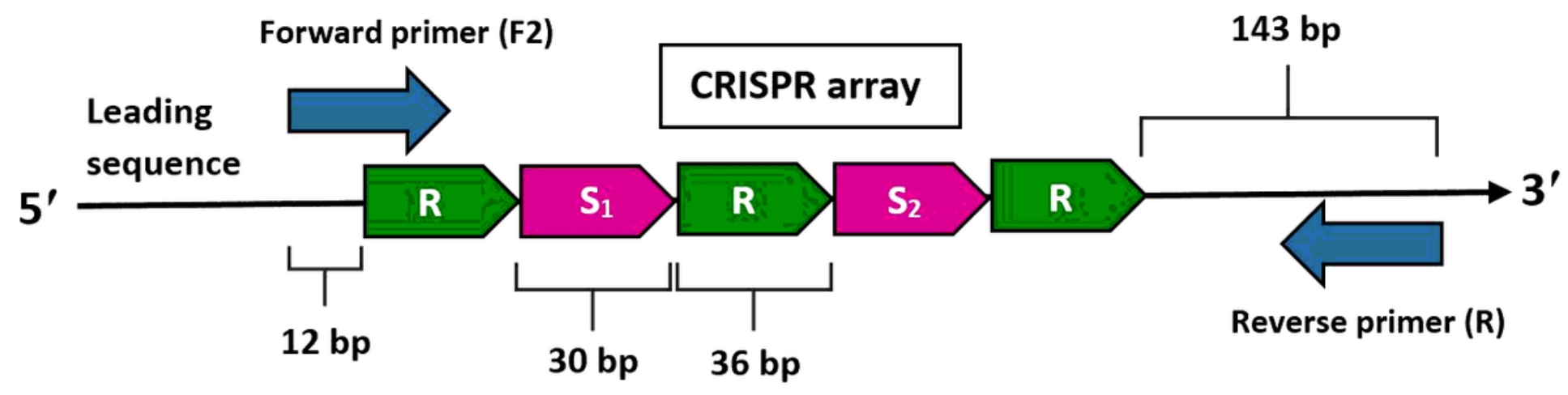

Figure 4

Schematic illustration of the CRISPR array structure and the targeting primers. $\mathrm{R}$ indicates the consensus direct repeat (DR) of the $C$. jejuni CRISPR array (36 bp); $S$ indicates a spacer sequence (30 bp), which is always flanked by two DRs. The C. jejuni DR-specific forward primer (F2) is 25 bases long and overlaps the first 13 bases of the DR

\section{Supplementary Files}

This is a list of supplementary files associated with this preprint. Click to download.

- SupplementaryTableS1.pdf

- SupplementaryTables2.pdf

- SupplementaryTableS3.pdf 